\title{
Saksan kielestä vironnettu suomen kielen oppikirja - Soome keele õperaamat iseõppijatele (1919)
}

\author{
MARJA JÄRVENTAUSTA \\ KöInin yliopisto
}

Tiivistelmä. Vuonna 1919 ilmestyi Virossa suomen kielen oppikirja Soome keele õperaamat iseõppijatele, joka on käännös vuonna 1890 ilmestyneestä saksankielisestä oppikirjasta Praktische Grammatik der Finnischen Sprache für den Selbstunterricht. Oppikirjan tekijä kätkeytyy pseudonyymin M. Wellewill taakse, ja teoksen virontajaa ei mainita lainkaan. Tässä artikkelissa tarkastelen Õperaamatun ja sen lähtötekstin välisiä eroja. Oletuksenani on, että käännöksessä hyödynnetään jollain tapaa suomen ja viron samankaltaisuutta ja että Suomen ja Viron välinen kulttuurinen läheisyys näkyy ainakin jonkin verran myös käännöksessä. Lisäksi vertaan Õperaamatua Johannes Aavikin oppikirjaan Praktilik Soome keele õpetus (1908) ja Lauri Kettusen teokseen Soome keele õpiraamat (1920). Lähestyn näiden kolmen oppikirjan eroja ja yhtäläisyyksiä tarkastelemalla lähemmin niiden tapaa käsitellä suomen sijamuotoja ja pyrin sijamuotojen kautta tekemään joitakin yleistyksiä kunkin oppikirjan ominaispiirteistä. ${ }^{1}$

Avainsanat: historiallinen oppikirjatutkimus; suomi vieraana kielenä; virolaiset suomen kielen oppikirjat

Tämän artikkelin välittöminä virikkeinä ovat olleet Lähivertailujen viime numerossa ilmestyneet Marjut Vehkasen (2018, ks. myös Vehkanen 2017) ja Maria Kokin (2018) oppikirjatutkimusta käsittelevät artikkelit. Kiitos kummallekin! 


\section{Aluksi}

Sata vuotta sitten, vuonna 1919, ilmestyi Tallinnassa vironkielinen suomen kielen oppikirja, Soome keele õperaamat iseõppijatele, jonka alaotsikkona on Grammatik, kõnelemised, harjutused ja sõnastik. Oppikirjan kirjoittaja on M. Wellewill, ja kyseessä on, vaikka sitä ei missään mainitakaan, vironnettu laitos Wellewillin vuonna 1890 julkaistusta saksankielisestä suomen kielen oppikirjasta Praktische Grammatik der Finnischen Sprache für den Selbstunterricht mit Lesestücken, Gesprächen und Wörterbuch ['Suomen kielen käytännöllinen kielioppi itseopiskeluun sisältäen lukukappaleita, keskusteluja ja sanakirjan']. Millainen tämä Wellewillin Õperaamat on ja miksi se vironnettiin, vaikka vironkielisille suomenoppijoille oli jo tarjolla Aavikin Praktilik Soome keele õpetus (1908)? Jälkimmäiseen kysymykseen on mahdotonta vastata, koska Õperaamatussa ei ole minkäänlaista esipuhetta tai johdantoa, jossa selvitettäisiin teoksen taustoja tai kerrottaisiin, minkä vuoksi katsottiin hyväksi julkaista saksankielisestä oppikirjasta vironkielinen laitos vielä lähes kolmekymmentä vuotta alkuperäisen teoksen ilmestymisen jälkeen. ${ }^{2}$ Tässä artikkelissa tarkastelenkin sitä, millainen oppikirja Opperaamat oikein on. Aavikin (1908) ja Kettusen (1920) oppikirjoihin verrattuna Õperaamat on jäänyt melko vähälle huomiolle. Esimerkiksi Valge, joka esittelee vuosien 1881-1967 välillä ilmestyneitä virolaisia suomen kielen oppikirjoja, ei käsittele Õperaamatua lainkaan, vaikka mainitseekin sen lähdeluettelossaan (Valge 1987: 179-181, 185).

Tarkastelen Õperaamatua pääosin kahdesta näkökulmasta. Ensimmäinen näkökulma koskee oppikirjan kääntämistä eli toimittamista uudelle kohderyhmälle. Kun oppikirjan saksankielinen kohderyhmä muuttuu vironkieliseksi, metakieli muuttuu, mutta muutosprosessissa tapahtuu paljon muutakin. Ensinnäkin kuvattava kieli - suomi - poikkeaa rakenteeltaan huomattavasti alkuperäisen kohderyhmän kielestä mutta on rakenteeltaan hyvin samankaltainen kuin uuden kohderyhmän kieli. Voisi siis olettaa, että käännöksessä ainakin jollain tapaa

\footnotetext{
2 Alkuperäisteoksen toinen painos ilmestyi 1906 ja kolmas 1922.
} 
SAKSAN KIELESTÄ VIRONNETTU SUOMEN KIELEN OPPIKIRJA ..

hyödynnetään suomen ja viron samankaltaisuutta. Myös suomalainen kulttuuri oli 1800-luvun lopun saksankieliselle kohderyhmälle paljon etäisempi ja oudompi kuin 1900-luvun alun virolaisille. Voisi siis olettaa, että kulttuurinen tuttuus näkyisi jollain tapaa myös käännöksessä. Tarkastelen näitä kahta olettamusta vertaamalla lähtötekstin ja käännöksen kielellistä ja kulttuurista ainesta toisiinsa. Toinen näkökulmani koskee Õperaamatun suhdetta sen ajallisesti lähimpiin vertailukohtiin, Aavikin ja Kettusen oppikirjoihin. Lähestyn näiden kolmen oppikirjan eroja ja yhtäläisyyksiä tarkastelemalla, miten niissä käsitellään suomen sijamuotoja ja millaisia nimityksiä sijoita käytetään (vrt. Kok 2018). Sijamuotojen kautta pyrin tekemään joitakin yleistyksiä kunkin oppikirjan ominaispiirteistä.

Nykyisiä oppikirjojen tutkimuksessa käytettyjä menetelmiä, käsitteistöä ja kriteereitä ei sellaisinaan voi soveltaa sadan vuoden takaisiin oppikirjoihin. Käsitys kielestä, kielen oppimisesta ja opettamisesta on muuttunut perinpohjaisesti, samoin koko se yhteiskunnallinen ja kulttuurinen konteksti, johon oppikirjat kirjoitettiin. Historiallinen oppikirjatutkimus voi kuitenkin hyötyä nykytutkimuksesta. Tämä artikkeli nojaa erityisesti saksalaiseen ja saksa vieraana kielenä -oppikirjoja koskevaan tutkimukseen (esim. Krumm 2010; Rösler \& Schart 2016; Fäcke 2016; MLZ 2017: 206-209).

Käytän Wellewillin oppikirjan alkuperäisestä saksankielisestä laitoksesta lyhennettä Praktische Grammatik (esimerkeissä PG) ja vironkielisestä laitoksesta lyhennettä Õperaamat (esimerkeissä ÕR). Alkuperäisestä saksankielisestä laitoksesta puhun myös lähtötekstinä, kun vertaan Õperaamatua siihen. Silloin kun käsittelen saksan- ja vironkieliselle laitokselle yhteisiä seikkoja, puhun yksinkertaisesti vain Wellewillin oppikirjasta. 


\section{2. Õperaamat oppikirjana ja oppikirjan käännöksenä}

\subsection{Lähtötekstistä}

Wellewillin Praktische Grammatik ilmestyi wieniläisen A. Hartlebenin kustantamon vieraiden kielten oppikirjojen sarjassa. Sarjan oppikirjat pyrittiin laatimaan noudattaen yhteneväistä mallia, jonka avulla piti olla mahdollista oppia nopeasti ja monipuolisesti mitä tahansa kieltä myös itsenäisesti ilman opettajan apua. Esipuheessa (PG III) todetaan, että oppikirja on tarkoitettu kaikille niille, jotka haluavat oppia suomea helposti ja nopeasti tieteen, kirjallisuuden, kaupan tai turismin tarpeisiin. Tavoitteena oli helppotajuinen oppikirja, jossa käytännönläheisyys määräsi, miten ja missä järjestyksessä opetettava kielenaines esitettiin (PG IV).

Esipuheessa tähdennetään, että kieliopin säännöt on laadittu suomen kieliopin parhaisiin asiantuntijoihin nojaten (PG III). Setälän (1891: 192) mukaan Wellewillin päälähteenä on "silminnähtävästi ollut Kockströmin oppikirja, josta hän on saanut hyvin suuren osan lukukappaleissa esiintyviä esimerkkejä sekä sääntöjä”. Kockströmin oppikirjan (1881) ohella Wellewill on kuitenkin lainannut usein aivan sanasta sanaan myös Kockströmin koulukieliopin saksankielistä käännöstä vuodelta 1876, vaikkei sitä lähteissään mainitsekaan (Järventausta 2017: 68-70). Hieman kärjistäen voisikin sanoa, että Wellewillin kielioppisäännöt ovat peräisin Kockströmin kieliopista kun taas oppikirjan perusrakenne eli kielioppiasioiden esitysjärjestys perustuu Kockströmin oppikirjaan.

Wellewillillä näyttää olleen hyvät ja ajantasaiset tiedot suomen kielen kieliopeista ja oppikirjoista, ja hänellä oli myös kyky laatia niiden pohjalta varsin kelvollinen suomen kielen oppikirja. Kustantajan käytännön kielitaitoon tähtäävää ohjelmaa oppikirja tosin toteuttaa vain osittain, sillä otsikossa mainittujen keskustelujen ja lukukappaleiden osuus on vähäinen, eivätkä käännösharjoitukset oikein sovellu itseopiskeluun. Suomessa oppikirjaa ei liiemmin noteerattu. Setälä (1891: 192) kuitenkin toteaa lyhykäisessä arviossaan, että "[k]oska kirja on 
SAKSAN KIELESTÄ VIRONNETTU SUOMEN KIELEN OPPIKIRJA ..

käytännöllisesti järjestetty ja jotenkin vapaa suoranaisista virheellisyyksistä, niin se varmaankin vastaa sitä tarkoitusta, jota sillä on tahdottu täyttää". Gustafssoninin (1892: 74) mielestä oppikirja on "en i det hela pålitlig elementarbok för utländingar". Wellewillin henkilöllisyyttä kumpikaan ei tiedä tai paljasta: Gustafsson (1892: 74) toteaa, että oppikirjan laatija on "en oss obekant författare". Setälä ei puutu tekijän henkilöön lainkaan. (Wellewillistä ks. myös Järventausta 2017: 70.)

\subsection{Kielioppiseikoista}

Oppikirjan johdannossa käsitellään lyhyesti suomen kielen keskeisiä foneettisia ja fonologisia kysymyksiä: äänteitä, sanapainoa, sanojen vartaloita ja päätteitä, vokaalisointua ja tavutusta. Äänteiden kuvauksessa Õperaamat poikkeaa selvästi lähtötekstistä silloin, kun lähtötekstin kuvaus perustuu saksan ja suomen välisiin eroihin. Kun saksankieliselle oppijalle kerrotaan, että suomen kielen ääntäminen ei tuota vaikeuksia, koska suomessa ei ole muiden kielten, esimerkiksi englannin, hankalia äänteitä ja koska jokaista kirjainta kuvaa aina samaa äänne (PG 1), vironkieliselle oppijalle riittää, kun todetaan, että suomen kielen ääntäminen ei aiheuta ongelmia, koska "nagu Eesti keelegi, samuti wälja räägitakse nagu kirjutatakse" (ÕR 3). ${ }^{3}$ Saksankieliselle oppijalle vakuutetaan, että jokainen saksalainen, joka hallitsee äidinkielensä ääntämisen, voi helposti ja ilman opettajan apuakin oppia ääntämään suomen kieltä oikein.

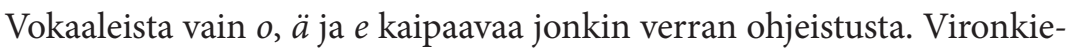
liselle oppijalle riittää, kun todetaan vokaalien ääntyvän "just niisma kui Eesti keeles; ainult $y^{4}$ kõlab just nagu meie ü” (ÕR 3). Konsonanttien ääntämisessä saksankielistä oppijaa muistutetaan siitä, ettei sananalkuisia konsonantteja saa ääntää liian terävästi - saksan kielessähän sananalkuiset klusiilit ovat aspiroituneita - ja että kaksoiskonsonantteja merkitään aina kahdella kirjainmerkillä. Virolaiselle oppijalle sen sijaan

\footnotetext{
Grafeemin ja foneemin eroa ei tehdä kummankaan kielisessä versiossa selväksi. Õperaamatun leipäteksti on fraktuuraa, kielenaines antikvaa; tässä ja jäljempänä antikvaa on merkitty kursiivilla.
} 
on tarpeen tähdentää, että suomen kielen $<\mathrm{p}, \mathrm{t}, \mathrm{k}>$ äännetään niin kuin viron kielen $<\mathrm{b}, \mathrm{d}, \mathrm{g}>$ (Õperaamatun mukaan lyhyet soinnittomat klusiilit ovat "pehmed”), esimerkiksi “äiti (ema) = loetakse: äidi” (ÕR 4). Kaksi soinnitonta klusiilia puolestaan luetaan lyhyenä, esimerkiksi "tyttö, seal loetakse seda sõna, nagu oleks temas üksainus $t$ nimelt tütö” (ÕR 4). Õperaamatusta on jätetty kokonaan pois lähtötekstissä esiintyvä huomautus siitä, että joidenkin sanojen lopussa esiintyy voimakkaampana kuuluva henkäys, jota ei kuitenkaan enää merkitä kirjoituksessa (PG 2).

Sanapainoa Õperaamat kuvaa jokseenkin samoin kuin lähtöteksti, mutta lisää, että "nagu Eesti keeleski” pääpaino on suomessa aina sanan ensimmäisellä tavulla. Vartaloa ja päätteitä, vokaalisointua ja tavutusta Õperaamatussa käsitellään lähtötekstin mukaisesti. Johdantoluvun lopettavasta ääntämisharjoituksesta löytyy taas eroja, sillä saksankieliselle oppijalle ääntämisohjeita on merkitty erilaisin tarkkein (PG 4), kun taas vironkielinen oppija saa tyytyä paljon ylimalkaisempiin ohjeisiin (ÕR 6).

Varsinainen oppikirja - lähtötekstissä käytetään sanaa kielioppi sisältää 60 kappaletta, jotka on laadittu yleensä aina saman kaavan mukaan. Ensiksi esitellään uusi kielioppiasia sääntöjen avulla (Reeglid), sitten luetellaan uusia sanoja vironkielisine vastineineen (Sõnad), ja lopuksi seuraavat harjoitukset (Harjutused), joissa kielioppia ja sanastoa harjoitellaan kääntämällä lauseita ensiksi passiivisesti suomesta viroon ja sitten aktiivisesti virosta suomeen. Kyseessä on siis varsin perinnäinen kielioppi-käännös-menetelmää toteuttava oppikirja. - Menetelmästä tarkemmin esim. Elomaa (2009: 61, 66, 109), MLZ (2017: 116-118), Reinfried (2016: 622-623).

Äänneseikkoja lukuun ottamatta kieliopin sääntöjä valotetaan lähtötekstissä vain harvoin saksan ja suomen erojen avulla, eikä Õperaamatussakaan vertaileva näkökulma juuri nouse esiin. Jonkin verran kontratiivisuus kuitenkin näkyy. Saksankieliselle oppijalle esimerkiksi tähdennetään sitä, että suomen substantiiveilla ei ole sukua (1a) eikä suomen kieli tunne määräistä tai epämääräistä artikkelia (2a). Vironkielisen oppijan näkökulmasta molemmat huomautukset ovat oikeastaan täysin 
tarpeettomia. Niinpä Õperaamatussa vain todetaan, että substantiiveilla ei suomessa - niin kuin ei virossakaan - ole sukua (1b) eikä suomen kielessä ole artikkelia (2b).

(1a) Im Finnischen giebt es bei den Hauptwörtern keinen Geschlechtsunterschied. (PG 7)

(1b) Soome keeles ei ole, nagu Eesti keeleski, peasõnadel suguwahet. (ÕR 7)

(2a) Es existirt weder ein bestimmter, noch ein unbestimmter Artikel. (PG 7)

(2b) Artiklit Soome keeles ei ole. (ÕR 7)

Kun suomen sijamuodot ovat ensimmäisen kerran esillä, lähtötekstissä kerrotaan, että suomessa on kaksi lukua, yksikkö ja monikko, ja viisitoista sijaa. Sijamuotojen runsauden oletetaan ilmeisesti hämmästyttävän saksankielistä oppijaa, koska heti perään lisätään, että useimmat näistä niin sanotuista sijoista ilmaisevat yksinkertaisesti vain prepositionaalisia suhteita, joihin siis muut kielet käyttävät prepositioita (3a). Opperaamatusta tämä lisäys on jätetty pois, onhan sijojen runsaus vironkieliselle oppijalle tuttua jo omasta äidinkielestä (3b).

(3a) Die finnische Sprache hat zwei Zahlformen, den Singular und den Plural und fünfzehn Casus. Doch bezeichnen die meisten dieser sogenannten Casus nichts als Präpositionalverhältnisse, wofür eben andere Sprachen sich der Präpositionen bedienen. (PG 20)

(3b) Soome keelel on samuti kui Eesti keeles ainus ja mitmus ja wiisteistkümmend käänet. (ÕR 20)

Suomen kielen passiivi käsitellään saksan ja viron eroista johtuen lähtötekstissä ja Õperaamatussa varsin eri näkökulmista, vaikka molemmissa todetaankin, ettei suomessa oikeastaan ole "oikeaa" passiivia. Saksankieliselle oppijalle selitetään, että suomen passiiviksi kutsuttua impersonaalista muotoa voidaan ilmaista saksassa man-pronominilla ja verbin 3. persoonan yksikkömuodolla (PG 70), Õperaamatussa sen sijaan suomen passiivin muotoa verrataan viron -takse-päätteeseen (ÕR 71). 
Joskus Õperaamatussa selitetään kielioppiasioita huomattavasti lyhyemmin kuin lähtötekstissä, joskus taas selitykset jätetään kokonaan pois ikään kuin luottaen siihen, että kielten samankaltaisuuden vuoksi vironkieliselle oppijalle riittävät suomenkielisten esimerkkilauseiden käännökset. Referatiivisen lauseenvastikkeen käsittely on tästä hyvä esimerkki. Lähtötekstissä ilmiö kuvataan yksityiskohtaisesti ja melko teoreettisesti kokonaan ilman esimerkkejä (4a), Õperaamatussa sitä vastoin kieliopillinen kuvaus on äärettömän niukka, muta ilmiötä valaistaan esimerkin avulla (4b):

(4a) Wenn ein mit että (daß) eingeleiteter Nebensatz bei einem Zeitworte als Object steht, kann derselbe verkürtzt werden, indem man die Conjunction wegläßt und das Prädicat in den Genetiv Sing. des Particip I setzt, wenn die Handlung des Nebensatzes mit der Haupthandlung gleichzeitig ist, oder im Vergleich mit derselben bevorsteht; in den Genetiv Sing. des Particip II, wenn die Handlung im Vergleich mit der Haupthandlung vollendet ist. (PG 114)

'Kun että-sanalla alkava sivulause on verbin objektina, se voidaan lyhentää jättämällä se taivuttamatta ja laittamalla predikaatti joko 1. partisiipin yksikön genetiiviin, jos sivulauseen toiminta on päälauseen kanssa samanaikaista tai siihen verrattuna edessä olevaa, tai 2. partisiipin yksikön genetiiviin, jos toiminta on päätoimintoon verrattuna loppuun saatettu.'

(4b) Kõrwallauset, mis sõnaga että (et) algab, wõib ka pealausega ühendada, nätuseks: kuulen linnun laulavan - kuulen lindu laulawat (selle asemel et ütelda: kuulen, et lind laulab). (ÕR 115)

Samantapaisia ratkaisuja löytyy Õperaamatusta muitakin. Esimerkiksi ennen kuin lähtötekstissä ryhdytään käsitelemään verbien taivutusta, selitetään, että verbin vartalo saadaan indikatiivin preesensin 1. persoonan muodosta, että modus, tempus ja persoonapäätteet liitetään vartaloon ja että vokaalinvaihtelut noudattavat samaa kaavaa kuin substantiivien taivutuksessakin (PG 53). Õperaamat (s. 54) tyytyy vain toteamaan, että verbien oikeanlaista taivuttamista varten täytyy tuntea verbin vartalo, johon sitten päätteet liitetään. Kokonaan on jätetty pois esimerkiksi osa disjunktiivisten konjunktioiden käyttöä (PG 44), 
SAKSAN KIELESTÄ VIRONNETTU SUOMEN KIELEN OPPIKIRJA ..

translatiivin käyttötapoja (PG 55-56), ainesanojen yksiköllisen ja monikollisen käytön eroja (PG 91), vertailurakennetta (PG 104), päivämäärän ilmaisemista (PG 110) ja -Us-päätteisiä johdoksia (PG 121) koskevista selityksistä. Jos kuitenkin selityksiin liittyvät esimerkit on sälytetty, saattaa syntyä liiallisia yleistyksiä tai väärinkäsityksiä. Näin on laita esimerkiksi neljättä infinitiiviä käsiteltäessä, kun Õperaamatussa (s. 91) -minen-päätteinen verbaalisubstantiivi ja infiniittiset rakenteet rinnastuvat esimerkkien kautta, vaikka lähtöteksti tekee selvän eron niiden välillä (PG 90-91).

Kaiken kaikkiaan Õperaamat noudattelee kielioppiseikoissa varsin tarkoin lähtötekstiä. Poikkeamat lähtötekstiin ovat yleensä kahdenlaisia. Ensinnäkin Õperaamatun kääntäjä on poistanut lähtötekstistä huolellisesti kaikki viittaukset saksan ja suomen eroihin. Joitakin niistä on korvattu huomauttamalla viron ja suomen yhtäläisyyksistä tai eroista, joitakin jätetty kokonaan pois. Toiseksi kääntäjä on poistanut joitakin varsin yksityiskohtaisia ja teoriapainotteisia kieliopillisia selityksiä. Syyt voivat olla kahtaalla. Poistettujen selitysten voidaan katsoa olevan virolaiselle oppijalle tarpeettomia viron ja suomen samankaltaisuuden vuoksi. Todennäköisemmältä kuitenkin vaikuttaisi se, että kohderyhmäksi ei ole ajateltu - ei ainakaan yksinomaan - kieliopillisesti harjaantuneita oppijoita, minkä vuoksi kieliopillista painolastia on ollut syytä karsia. Vironkieliseen tekstiin kääntäjä ei ole tehnyt oikeastaan muita lisäyksiä kuin joitakin viittauksia viron ja suomen yhtäläisyyksiin.

\subsection{Kulttuurisesta aineksesta}

Suomen maantuntemukseen liittyviä aiheita tai muutakaan kulttuurista ainesta Wellewill ei käsittele oppikirjassaan juuri lainkaan. Kulttuurista ainesta toki löytyy esimerkeistä, käännösteksteistä ja jonkin verran myös lukukappaleista, etenkin aivan kirjan loppupuolelta. Sitä ei kuitenkaan käsitellä johdonmukaisesti tai tavoitteellisesti, vaan sitä on siroteltu sinne tänne. Esimerkiksi viimeisen kappaleen suomenkielisissä 
käännöslauseissa käsitellään saunomisen, Saimaan kanavan, Suomen asukasluvun ja Viaporin linnan antautumisen vuosipäivän lisäksi muun muassa Elton-järveä, Venäjän Itämeren laivastoa, Mozartia, Bartholomæus Diazia ja Kolumbusta (PG 137-138).

Õperaamatussa esimerkkien, käännösharjoitusten ja lukukappaleiden sisältö noudattelee lähes poikkeuksetta lähtötekstiä. Ainoastaan oppikirjan aloittavasta, suomen kieleen johdattelevasta kappaleesta löytyy joitakin selvästi erilaisia painotuksia. Kun lähtötekstissä sanotaan, että suomen kieli on uralilaisen kieliperheen balttilaisen haaran kehittynein jäsen, Õperaamatussa todetaan, että suomen kieli on yksi uralilais-altailaisen kielikunnan kehittyneimmistä kielistä. Lähtötekstin toteamus, että suomen kielioppi tarjoaa oppijalle paljon omintakeista ja vierasta, on myös jätetty viron ja suomen samankaltaisuuden vuoksi kokonaan pois. Samoin on jätetty pois maininta Suomen kansanrunouden "rikkaasta aarteesta", jonka lähtötekstissä sanotaan saavuttaneen ulkomaillakin ansaittua huomiota (PG 1).

Jonkin verran Õperaamatussa on mukautettu ja ajantasaistettu esimerkkien ja käännösharjoitusten sisältöä. Muun muassa keisari Aleksanteria koskevia erityisen myönteisiä viittauksia on karsittu vironkielisistä käännöslauseista:

(5a) Alexander, Kaiser von Rußland, ist Großfürst von Finnland. Die Macht Kaiser Alexanders ist groß. Die Bewohner des Reiches lieben Kaiser Alexander. (PG 69)

'Aleksanteri, Venäjän keisari, on Suomen suuriruhtinas. Keisari Aleksanterin valta on suuri. Valtakunnan asukkaat rakastavat keisari Aleksanteria.'

(5b) Aleksander oli Wenemaa keiser. Ta oli ühtlasi Soomemaa suurwürst. (ÕR 71)

Suomenkielisiin käännöslauseisiin jokunen tällainen lause on jäänyt (esim. ÕR 70). Muut muutokset ovat vähäisiä: Turun asukasluku on noussut 22 000:sta (PG 69) 29 000:een (ÕR 70), Wien (PG 135) on muutettu Tartoksi (ÕR 141) ja vuosiluku 1885 (PG 22) on vaihtunut vuodeksi 1919 (ÕR 22). Kaiken kaikkiaan muutosten tarve on kuitenkin ollut 
lähes olematon, sillä lähtötekstin esimerkit ja käännöslauseet eivät ole yleensä saksankieliseen lähtökulttuuriin sidoksissa tai sillä tavoin aikatai paikkasidonnaisia, että niitä tarvitsisi mitenkään erityisesti muokata vironkieliselle oppijalle. Poikkeuksena on seuraava Suomen ja Itävallan valuuttakursseja koskeva alaviite, joka on poistettu Õperaamatusta:

(6) Eine finnische markka ist circa 45 kr. ö. W. (PG 27, alaviite) 'Yksi suomen markka on n. 45 kruunua Itävallan valuuttaa.'

Õperaamatusta on karsittu myös muutamia sellaisia alaviitteitä, joissa saksankieliselle oppijalle selitetään suomalaista kulttuuria ja yhteiskuntaa käsitteleviä ilmiöitä. Viron ja Suomen kulttuurisen läheisyyden vuoksi kääntäjä ei ilmeisesti ole katsonut virolaisen oppijan tarvitsevan tällaisia lisäselvityksiä:

(7) Runo bezeichnet das finnische Volkslied. Das Versmaß dieser runot besteht aus zwei trochäischen Dipodien $(-v-v-v-v)$. Der Reim kommt zuweilen vor, doch ist die Sprache dazu weniger geeignet. Die älteren Lieder dieser Art haben die Eigenheit, daß mehrere Verse nach einander denselben Gedanken wiederholen. (PG 69, alaviite sanalle runoelma)

'Runo tarkoittaa suomalaista kansanlaulua. Näiden runojen mitta muodostuu kahdesta trokeista dipodista $(-v-v-v-v)$. Loppusointua esiintyy satunnaisesti, mutta se ei sovellu kieleen kovin hyvin. Tällaisille vanhemmille runoille on ominaista, että useammassa peräkkäisessä säkeessä toistetaan sama asia.'

(8) Das Baden ist eine finnische Nationalsitte, und fast jeder Bauer hat neben seinem Haus eine besondere Badestube. (PG 137, alaviite sanalle sauna)

'Kylpeminen on Suomessa kansallinen tapa, ja lähes jokaisella talonpojalla on talonsa vieressä erillinen saunatupa'

Õperaamatusta löytyy sen sijaan kiinnostava alaviite, jossa kohdekulttuuria selitetään oppijan oman kulttuurin kautta:

(9) Huwitaw on lugeda: Elias Lönnrot, Elämäkerrallisia piirteitä - kirjoittanut Aug. Ahlquist. Lönnrot - Soome Kreutzwald. (ÕR 147) 
Õperaamatussa myös kehotetaan lukijaa lisäoppia saadakseen hankkimaan käännöskirjallisuutta:

(10) Edasiõppimiseks soowitan osta soomekeelseid tõlkeid Eesti raamatutest. Neid on olemas juba kaunis kogu. Nimetan siin ainult Aino Kallase raamatuid. (ÕR 147)

\subsection{Kokoavasti}

Kun Wellewillin suomen kielen oppikirja ilmestyi, kielenopetuksessa oli vallitsevana ns. kielioppi-käännös-menetelmä, ja oppikirjat laadittiin sen mukaisesti (ks. esim. Götze 1994). Menetelmä oli alun perin kehitetty klassisten kielten opetukseen, ja sen keskeinen tavoite oli kieliopin ja sanaston hallinta, jota harjoitettiin kääntämällä. Lähtö- ja opetuskielenä oli oppijoiden ensikieli ja päämääränä kohdekielen kirjallinen hallinta. (MLZ 2017: 116-117.) Wellewillin oppikirja on melko tyypillinen kielioppi-käännös-menetelmää noudattava oppikirja, mikä ilmenee jo yksittäisten kappaleiden rakenteestakin: ensiksi kieliopin sääntöjä, sitten sanastoa ja lopuksi käännösharjoituksia. Kielioppi-käännös-menetelmä on formaalinen ja deduktiivinen, sillä sen keskiössä ovat kielelliset kategoriat ja paradigmat, ja oppiminen etenee abstrakteista säännöistä niiden soveltamiseen. Wellewillin oppikirjassakin selitetään vain harvoin jonkin kieliopillisen muodon semanttista sisältöä tai käyttötapoja, joskin poikkeuksiakin löytyy esimerkiksi joidenkin sijamuotojen käsittelyssä (esim. PG 55-56). Kielioppi-käännös-menetelmän mukaisesti Wellewillin oppikirja etenee jonkinlaista kieliopillista progressiota noudattaen. Kielioppiseikkojen esittämisjärjestys on näissä varhaisissa oppikirjoissa paljolti intuitiivinen: edetään tavallisemmista, helpommista, välttämättömämmistä rakenteista harvinaisempiin, vaikeampiin, valinnaisempiin - aina sen mukaan, mitä oppikirjan laatija on pitänyt tavallisena, helppona, välttämättömänä. Wellewill tosin perusti progressionsa paljolti esitysjärjestykseen, joka oli laadittu alun perin Suomen ruotsinkielisten koulujen suomen kielen opetukseen, eikä oppikirjan virontajakaan ole nähnyt syytä muuttaa sitä. 
SAKSAN KIELESTÄ VIRONNETTU SUOMEN KIELEN OPPIKIRJA ...

Wellewillin oppikirja syntyi kuitenkin aikana, jolloin reformiliike oli jo noussut vaatimaan periaatteellisia uudistuksia vieraiden kielten opetukseen (MLZ 2017: 113-114). Lisäksi se ilmestyi sarjassa, joka painotti käytännön kielitaidon merkitystä. Siksi ei olekaan yllättävää, että se poikkeaa jo jonkin verran kielioppi-käännös-menetelmän tiukimmista perinteistä ja antaa tilaa käytännön kielitaidon harjoittamiselle. Tämä näkyy erityisesti siinä, että oppikirjaan on liitetty joitakin luku- ja keskusteluharjoituksia ja että kääntämistä harjoitellaan myös lähtökielestä vieraaseen kieleen. Harjoitusten tekstit käsittelevät, toisin kuin perinnäisimpien kielioppi-käännös-menetelmän mukaisten oppikirjojen harjoitukset (ks. Elomaa 2009: 109), yleensä melko arkipäiväisiä aiheita, mikä osaltaan edistää käytännön kielitaidon omaksumista.

Wellewillin oppikirjan ilmeisin heikkous on sen käännöslauseet, jotka ovat joitakin vähäisiä muutoksia lukuun ottamatta siirtyneet lähtötekstistä lähes sellaisinaan myös Õperaamatuun. Esimerkkilauseissa ei ole jälkeäkään kommunikatiivisuudesta, vaan ne ovat sekalainen joukko irrallisia lauseita, joissa kerrataan kappaleen sanastoa ja kielioppiasioita. Toinen harmittava seikka, joka koskee vain Õperaamatua, on se, että "Wellewill'i iseõpetaja kubiseb lugematuist vigadest", niin kuin Ernits (1929: 103) toteaa. Suomenkieliset käännöslauseet todellakin vilisevät virheitä, ja onpa painovirheitä pujahtanut kielioppisääntöihinkin.

\section{3. Õperaamat ensimmäisten vironkielisten suomen kielen oppikirjojen joukossa}

Valgen (1987: 175) mukaan virolaisille kirjoitetut suomen kielen oppikirjat on tarkoituksenmukaista jakaa kolmeen jaksoon. Ensimmäinen jakso kattaa vuodet 1881-1908 ja toinen jakso, johon Opperaamatkin kuuluu, vuodet 1908-1947. Tämän toisen jakson "huippunimiksi” Valge (mts. 179) nostaa Johannes Aavikin ja Lauri Kettusen. Õperaamatua hän ei tarkastele lähemmin, mutta mainitsee sen kuitenkin artikkelinsa lähdeluettelossa (mts. 185). Vertailen seuraavassa Õperaamatua näiden kahden "huippunimen" oppikirjoihin eli Aavikin Praktilik Soome keele 
õpetukseen (1908) ja Kettusen Soome keele õpiraamatuun (1920), joiden väliin se ajallisesti sijoittuu. Vertailun painopisteeksi olen valinnut suomen sijamuodot, joita tarkastelen niin terminologian (vrt. Kok 2018) kuin kieliopillisen kuvauksenkin (vrt. Vehkanen 2017) kannalta.

Ensimmäisen jakson oppikirjoissa sijamuodoista käytetään niiden latinalaisperäisiä nimityksiä. Ensimmäisen vironkielisen suomen kieliopin laati Mihkel Veske, ${ }^{5}$ jonka vähän yli 50-sivuinen Soome keele õpetus ilmestyi 1881. Suomen sijamuotojen lukumäärän ja nimitykset Veske näyttää lainanneen Eurénin kieliopista (1849: 39) ja lisänneen joukkoon vielä akkusatiivin (Weske 1881: 14-18). Vironkielisiä vastineita ei Veske suomen sijoille tarjoa, mutta mainitsee alaviitteessä (mts. 17), että sijoista käytetään suomenkielisiäkin nimityksiä, sellaisia kuin nimentö, omanto, osanto jne. Myös M. Neumann käyttää vuonna 1903 julkaisemassaan vironkielisessä suomen kieliopissa suomen sijoista ainoastaan latinalaisperäisiä nimityksiä ja sanoo syyksi sen, että "Eesti keeles need nimetused veel kindlaks ei ole seatud; pealegi ei õpetata Eesti keelt koolides nii palju, et Eesti keeleteadlised sõnad üleüldiselt mõistetavad oleksivad" (siteerattu Valgen 1987: 178 mukaan). Huomautus on kiinnostava siksi, että kuitenkin jo vuonna 1884 oli ilmestynyt Karl August Hermannin laatima ensimmäinen vironkielinen viron kielioppi. Sen terminologia, esimerkiksi juuri sijamuotojen nimitykset, olisi ollut hyvin sovellettavissa myös suomen kielen kuvaukseen, onhan suurin osa Hermannin laatimasta vironkielisestä terminologiasta vielä nykyisinkin käytössä (Kasik 1999: 90).

\subsection{Johannes Aavikin Praktilik Soome keele õpetus (1908)}

Kun Johannes Aavik vuonna 1908 julkaisi suomen kielen oppikirjansa, se ei siis ollut ensimmäinen lajissaan. Mutta "[s]elityksissä käytetty viro ja äidinkielinen termistö olivat heti Aavikin oppikirjan ensimmäisen painoksen edistysaskelia" (Valge 1987: 179). Suomen sijamuodoista Aavik käyttää oppikirjassaan kuitenkin aina niiden latinalaisperäisiä

5 Kielioppi on saksankielinen, ja tekijän nimestä käytetään muotoa Michael Weske. 70 
nimityksiä, vaikka mainitseekin taulukkomuotoisessa yhteenvedossa myös sijojen vironkieliset nimitykset (Aavik 1908: 102-103). Vironkieliset nimitykset vastaavat täysin Herrmannin (1884: 33) viron sijamuodoista käyttämiä nimityksiä, vain instruktiivin vironnos on ilmeisesti Aavikin oma.

Asetelma 1. Suomen kielen sijamuodot Aavikin oppikirjassa Praktilik Soome keele õpetus (1908)

\begin{tabular}{|c|c|c|c|}
\hline \multicolumn{3}{|c|}{ Kaasused } & \multirow{2}{*}{$\begin{array}{c}\text { Lõpud } \\
- \\
\end{array}$} \\
\hline Nominatiw & nimetaw & kes, mis & \\
\hline Genetiw & omastaw & kelle, mille & $-\mathbf{n}$ \\
\hline Akkusatiw & sihitaw & kelle, mille & $-\mathbf{n}$ \\
\hline \multicolumn{4}{|c|}{ Üleüldised kohalikud kaasused } \\
\hline Translatiw & saaw & $\begin{array}{l}\text { wanast: kuhu, } \\
\text { nüüd: kelleks, milleks }\end{array}$ & $-k s i$ \\
\hline Essiw & olew & $\begin{array}{l}\text { wanast: kus, } \\
\text { nüüd: kellena, millena }\end{array}$ & - na \\
\hline Partitiw & osastaw & $\begin{array}{l}\text { wanst: kust } \\
\text { nüüd: keda, mida }\end{array}$ & $-(\mathbf{t}) \mathbf{a}$ \\
\hline \multicolumn{4}{|c|}{ Wälimised kohalikud kaasused } \\
\hline Allatiw & alaleütlew & kuhu; kellele, millele & $-11 \mathrm{e}$ \\
\hline Adessiw & alalütlew & kus; kellel, millel & $-11 \mathrm{a}$ \\
\hline Ablatiw & alatütlew & kust; kellelt millelt & -lta \\
\hline \multicolumn{4}{|c|}{ Sisemised kohlikud kaasused } \\
\hline Illatiw & sisseütlew & kuhu; kellesse, millesse & -(h)an jne. \\
\hline Inessiw & seesütlew & kus; kelles, milles & - ssa \\
\hline Elatiw & seestütlew & kust; kellelst, millest & -sta \\
\hline Abessiw & ilmaütlew & kellta, milleta & $-\mathrm{tta}$ \\
\hline Komitatiw & kaasaütlew & ühes kellega, millega & - ne \\
\hline Instruktiw & wiisiütlew & kuidas, kuida wiisi & $-\mathrm{n}$ \\
\hline
\end{tabular}


Sijoja käsitellään kuitenkin jo kirjan alkupuolen varsinaisessa oppikirjaosassa. Ensimmäisenä oppija törmää hieman yllättäen, niin kuin Vehkanenkin (2017: 261) toteaa, illatiiviin jo pykälässä 7 (Aavik 1908: 9). Pykälän aiheena on jonnekin meneminen, minkä ilmaisemiseen illatiivia suuntasijana tarvitaan. Illatiivin pätteistä käsitellään tässä vaiheessa kuitenkin vain vokaalinpidennys $+-n$. Sulkeissa huomautetaan, että täydellinen taivutustaulukko löytyy kirjan loppupuolen kielioppiosasta. Illatiiviin kuitenkin palataan ennen sitä vielä parikin kertaa. Pykälässä 26 (mts. 35-36) esitellään -seen- ja -siin-pääteet ja pykälässä 56 (mts. 89-92) käsitellään suomen illatiivin erilaisia, erityisesti virosta poikkeavia käyttötapoja. Itse asiassa oppikirjaosassa käydään jo ennen taivutustaulukkoa läpi kaikki sijamuodot jollain tavoin. Monikon partitiivin ja genetiivin muodostusta selvitellään pykälässä 22 (mts. 30-31), genetiivin erityiskäyttöä, esimerkiksi nesessiivilauseiden genetiiviä, pykälässä 36 (mts. 49-50) ja partitiivin erityiskäyttöä, esimerkiksi tunnekausatiivien partitiivia, pykälässä 55 (mts. 88-89). Suomen kielen “omia" sijamuotoja komitatiivia ja instruktiivia valotetaan puolestaan pykälissä 39 ja 42 (mts. 55, 60). Kaikki paikallissijat käydään läpi pykälissä 56-61 (mts. 89-94). Ensimmäisenä on vuorossa illatiivi (mts. 89-92), jonka perusteellinen käsittely johtuu siitä, että "tarwitus on Soome keeles palju laialisem kui Eesti keeles” (mts. 89). Muut paikallissijat käsitellään pelkästään muutamien tyypillisten esimerkkien avulla. Kielioppiosassa palataan vielä illatiivin, partitiivin ja genetiivin päätteisiin (mts. 103-106), niin että etenkin illatiivin kuvaus on varsin kumulatiivinen. Periaatteessa Aavikin lähtökohtana on, että virolainen suomen kielen oppija tarvitsee kielten yhtäläisyyksien takia opastusta lähinnä vain silloin, kun kielet eroavat toisistaan (mts. III). Tarkemmin Aavikin kieliopista esim. Valge (1987: 179) ja Vehkanen (2017: 249-252, 257-262; 2018: 397-404).

Aavik oli ryhtynyt kirjoittamaan oppikirjaansa lähinnä siksi, ettei hänen tavoitteisiinsa soveltuvaa oppikirjaa ollut saatavilla: "Dr. Weske oma on wananenud ja otsa müüdud, Wellewill'i õpperaamat (Bibliothek der Sprachenkunde, 30. Hartleben's Verlag, Leipzig) on jälle liig kuiw ja igaw ning päälegi Saksa keeles" (mts. III). Oman oppikirjansa 
SAKSAN KIELESTÄ VIRONNETTU SUOMEN KIELEN OPPIKIRJA ..

pääasialliseksi kohderyhmäksi hän määrittelee ne, "kes Soome kirjakeelt kirjanduse lugemiseks soowiwad ära õppida” (mts. IV). Niille, jotka haluavat hankkia pelkästään käytännön kielitaidon esimerkiksi Suomeen suuntautuvien matkojen takia, hän suosittelee nimettömän kirjoittajan kolmikielistä keskusteluopasta Kõnelemised Eesti, Saksa ja Soome keeles vuodelta 1907 (Aavik 1908: IV). Tällaisen "parlöörin" ja Aavikin lähinnä passiiviseen kielitaitoon tähtäävän oppikirjan välimaastossa on kuitenkin tilaa myös Wellewillin teoksen tapaiselle oppikirjalle, jossa opittavan kielen peruskielioppi käydään pääpiirteissään läpi ja kielen käyttöä harjoitellaan jonkin verran käytännön tarpeisiinkin. Melko vaivaton tapa saada vironkielisten käyttöön tällainen perinnäisempi suomen kielen oppikirja olikin laatia Wellewillin kieliopista vironkielinen laitos kääntämällä leipäteksti ja saksankieliset käännösharjoitukset viroksi.

\subsection{Wellewillin Soome keele õperaamat iseõppijatele (1919)}

Wellewillin oppikirjan vironkielisen laitoksen kääntäjästä ei ole tietoa, mutta teoksen kustansi Eestimaa Kooliõpetajate Wastastikku Abiandmise Seltsi kirjastus. Niin kuin jo edellä kävi ilmi, Õperaamat noudattelee hyvin tarkasti lähtötekstiä, eikä suomen kielen sijojen esittely ja kuvaus tee tässä poikkeusta. Jo ensimmäisessä kappaleessa todetaan, että lauseen subjekti on nominatiivissa ja että nominatiivin pääte on monikossa " $t$ " (ÕR 7). Genetiiviin tutustutaan seuraavassa kappaleessa, missä sen kerrotaan vastaavan kysymykseen "kelle?" ja saavan yksikössä päätteen "n" (ÕR 8). Seuraavaksi käydään läpi sisäpaikallissijat, joiden kuvaus perustuu niiden lokaaliseen perusmerkitykseen. Inessiivistä todetaan, että se on sija, "mis ruumi tähendab, milles midagi peitub wõi sünnib" (ÕR 8), elatiivi puolestaan on sija "mis ruumi tähendab, kust keegi wõi midagi lahkub" ja illatiivi ilmaisee sen, "mille sisse midagi liigub" (ÕR 11). Ulkopaikallissijoista adessiivi ja allatiivi kuvataan samoin kuin sisäpaikallissijat: Adessiivi "tähendab kohta, kus wõi mille ligidal midagi on wõi sünnib", ablatiivi puolestaan "kohta wõi asja, kust ligidalt midagi kaugeneb" (ÕR 12). Allatiivi kuitenkin määritellään toisin, sillä se on Õperaamatun mukaan sija, joka 
“wastab küsimuse peale: kellele?” (ÕR 13). Päätteiden vokaalinvaihtelusta todetaan vain inessiivin yhteydessä että "kõwa lõpp on ssa ja pehme lõpp ssä" (ÕR 8). Illatiivin päätteestä "h-n" mainitaan, että konsonanttien väliin tulee $h$ :ta edeltävä vokaali ja että " $h$ " jää tietyin edellytyksin pois, esim. metsä-hän > metsään (ÕR 11). Paikallissijojen jälkeen, allatiivin kanssa samassa kappaleessa, käsitellään myös lyhyesti objektin sija akkusatiivi, jonka päätteenä on yksikössä "n” ja monikossa " $t$ " (ÕR 13).

Kun kappaleen 12 taulukkomaisessa yhteenvedossa (ÕR 20-21) luetellaan suomen kaikki sijamuodot päätteineen, lukijalle ovat jo tuttuja kieliopillisista sijoista nominatiivi, genetiivi ja akkusatiivi sekä kaikki sisä- ja ulkopaikallissijat. Sijojen määrittely on kuitenkin ollut epäyhtenäistä, sillä kuvaus on perustunut sijan perusmerkitykseen (paikallissijat allatiivia lukuun ottamatta) tai sijan syntaktiseen funktioon (nominatiivi ja akkusatiivi) tai sijaa ei ole varsinaisesti määritelty lainkaan, vaan on vain todettu, millaiseen kysymyssanaan se vastaa (genetiivi ja allatiivi).

Asetelma 2. Suomen sijamuodot Wellewillin oppikirjassa Soome keele õperaamat iseõppijatele (1919)

\begin{tabular}{|l|l|l|l|l|}
\hline & \multicolumn{2}{|c|}{ Käänete nimed } & \multicolumn{1}{c|}{ Ainsus } & \multicolumn{1}{c|}{ Mimus } \\
\hline 1 & Nimetaw & (nominatiiv) & - & $\mathrm{t}$ \\
\hline 2 & Osastaw & (partitiiv) & a,ä, ta, tä & ia, iä, ita, itä \\
\hline 3 & Omastaw & (genitiiv) & $\mathrm{n}$ & en \\
\hline 4 & Sihitaw & (akkusatiiv) & $\mathrm{n}$ & $\mathrm{t}$ \\
\hline 5 & Seesütlew & (inessiiv) & ssa, ssä & issa, issä \\
\hline 6 & Seestütlew & (elatiiv) & sta, stä & ista, istä \\
\hline 7 & Sisseütlew & (illatiiv) & h n [!] & ih-n \\
\hline 8 & Alalütlew & (adessiiv) & lla, llä & illa, illä \\
\hline 9 & Alaltütlew & (ablatiiv) & lta, ltä & ilta, iltä \\
\hline 10 & Alaleütlew & (allatiiv) & lle & ille \\
\hline 11 & Ilmaütlew & (abessiiv) & tta, ttä & itta, ittä \\
\hline 12 & Saaw & (translatiiv) & ksi & iksi \\
\hline 13 & Olew & (essiiv) & na, nä & ina, inä \\
\hline 14 & Kaasütlew & (komitatiiv) & - & ine \\
\hline 15 & Seletaw & (instruktiiv) & $\mathrm{n}$ & in \\
\hline
\end{tabular}


SAKSAN KIELESTÄ VIRONNETTU SUOMEN KIELEN OPPIKIRJA ...

Yhteenvedon jälkeen huomautetaan, että päätteet liitetään - "nagu meilgi" - vartaloon, mistä syystä sanojen taivuttamiseen tarvitaan aina sanan vartalo, joka saadaan poistamalla yksikön genetiivin muodosta loppu- $n$ (painovirheen takia " $n$ " on tosin tekstissä muuttunut "u":ksi) (ÕR 21). Päätteiden monikkomuodoissa kiinnittää huomiota genetiivin eri päätevarianttien puuttuminen ja muiden pääteiden $i$ :lliset muodot, joissa morfeemiraja on hämärtynyt. Merkintätapa on suora lainaus Kockströmin (1876: 11-12) saksankielisestä kieliopista.

Taivutuksen periaatteista siirrytään käsittelemään loput sijamuodot. Ensiksi vuorossa on partitiivi, josta todetaan, että se toimii sekä subjektin että objektin, erityisesti kielteisen lauseen objektin sijana. Partitiivi määritellään siis pelkästään syntaktisten funktioidensa kautta. Lisäksi käydään läpi päätevarianttien -a/-ä ja -ta/-tä käyttöä, minkä pohjalta sitten kuvataan melko tarkoin monikon genetiivin eri päättevariantit ja niiden distribuutio. Essiivi ja translatiivi, samoin kuin marginaaliset sijat ablatiivi, komitatiivi ja instruktiivi määritellään paikallissijojen tapaan semanttisesti; essiivistä tosin mainitaan vain sen temporaalinen käyttö. Õperaamatun esitystapa ei ole samalla tavoin kumulatiivinen kuin Aavikin, sillä sijamuotoihin ei yleensä enää palata kun ne on kerran käsitelty. Jonkinlaisena poikkeuksena voi pitää genetiiviä, jonka yksikkömuoto esitellään jo aivan oppikirjan alussa mutta monikkomuodot vasta aivan viimeisten sijapääteiden joukossa.

Õperaamatussa käytetään suomen sijamuodoista ensisijaisesti niiden vironkielisiä nimityksiä. Tässä suhteessa Õperaamat ei poikkea vain Aavikin oppikirjasta, vaan myös lähtötekstistään, missä käytössä ovat yksinomaan latinankieliset termit. Õperaamat käyttää sijoista samoja vironkielisiä nimityksiä kuin Aavik lukuun ottamatta komitatiivia ja instruktiivia. Õperaamatussa komitatiivi on "kaasütlew", Aavikilla (ja Hermannilla) "kaasaütlew”. Instruktiivista Aavik käyttää nimitystä “ wiisiütlew" ja Õperaamat nimitystä "seletaw". 


\subsection{Lauri Kettusen Soome keele õpiraamat (1920)}

Vaikka Õperaamatussa käydään suomen kielen koko peruskielioppi läpi, se ei sovellu akateemiseksi oppikirjaksi, sillä kielen kuvaus liikkuu joitakin poikkeuksia lukuun ottamatta kieliopin perusasioissa ja on paikoin myös epätarkka. Siksi ei ole yllättävää, että vain vuosi Õperaamatun ilmestytymisen jälkeen Lauri Kettunen julkaisi oman, selvästi akateemisemman oppikirjansa Soome keele õpiraamat (1920). Esipuheessa Kettunen toteaa, että oppikirjan tarkoitus on olla sekä käytännönläheinen että "kergesti teaduslik" (mts. v). Kohderyhmänä ovat kuitenkin myös yliopisto-opiskelijat, ja kuvauksen painopiste on suomen ja viron kielen samankaltaisuuden vuoksi kielten eroissa (mts. v-vi). Oppikirjan rakenne noudattaa perinteistä kieliopin kuvausjärjestystä. Ensimmäisessä ja toisessa luvussa kuvataan äänneoppi (mts. 1-15), kolmannessa luvussa muoto-oppi (mts. 15-84) ja viimeisessä, neljännessä luvussa, lauseoppi (mts. 84-138). Nominien taivutusta käsittelevä muoto-opin alaluku alkaa monikon i:n aiheuttaman morfofonologisen vaihtelun kuvauksella, minkä jälkeen vuorossa ovat sijamuodot. Oppikirjan kontrastoiva näkökulma käy hyvin esiin siitä tavasta, miten sijamuodot käsitellään. Ensiksi Kettunen esittelee suomen ja viron yhteiset ja suomen kielessä vaihtelemattomat sijamuodot, seuraavaksi morfologialtaan monimuotoiset sijat genetiivin, partitiivin ja illatiivin ja lopuksi suomen sijamuodot, joilla ei ole muodollista vastinetta virossa eli instruktiivin ja komitatiivin (mts. 17-24). Esitys voidaan koota vertailun helpottamiseksi taulukkomuotoon (ks. Asetelma 3).

Muoto-oppia kuvatessaan Kettunen käyttää sijoista ensisijaisesti niiden vironkielisiä nimityksiä (latinalaisperäiset nimet ovat sulkeissa). Poikkeuksena ovat instruktiivi ja komitatiivi, joilla ei ole vakiintunutta vironkielistä nimitystä ja joista Kettunen siksi käyttää niiden latinalaisperäisiä nimityksiä mainiten kuitenkin suomenkieliset nimitykset "keinonto" ja "seuranto". Sijojen päätteet kuvataan yksityiskohtaisesti, esimerkiksi allatiivin yhteydessä mainitaan päätteeseen liittyvä aspiraatio (mts. 19), ja monimuotoisten sijojen yhteydessä selvitetään 
Asetelma 3. Suomen kielen sijamuodot Kettusen oppikirjassa

Soome keele õpiraamat (1920)

\begin{tabular}{|c|c|c|c|}
\hline \multicolumn{4}{|c|}{ a. Soome ja eesti ühetaolised käänded } \\
\hline Nimetav & (nominatiiv) & - & $-\mathbf{t}$ \\
\hline Sihitav & (akusatiiv) & $-\mathbf{n}$ & $-\mathbf{t}$ \\
\hline Olev & (essiiv) & -na, -nä & -na, -nä \\
\hline Saav & (translatiiv) & $-\mathrm{ksi}$ & $-k s i$ \\
\hline Seesütlev & (inessiiv) & -ssa, -ssä & -ssa, -ssä \\
\hline Seestütlev & (elatiiv) & -sta, -stä & -sta, -stä \\
\hline Alaütlev & (adessiiv) & $-11 a,-11 a ̈$ & $-11 a,-11 a ̈$ \\
\hline Alaltütlev & (ablatiiv) & -lta, -ltä & -lta, ltä \\
\hline Alaleütlev & (allatiiv) & $-11 \mathrm{e}$ & $-11 \mathrm{e}$ \\
\hline Ilmaütlev & (abessiiv) & -tta, -ttä & -tta, -ttä \\
\hline \multicolumn{4}{|c|}{ b. Tuntavamalt lahkuminevad käänded } \\
\hline Omastav & (genitiiv) & $-\mathbf{n}$ & $\begin{array}{l}-(d) e n,-(t t) e n \\
\text {-en } \\
-(t) e n \\
-i n(-e n)\end{array}$ \\
\hline Osastav & (partitiiv) & $\begin{array}{l}-\mathrm{ta},-\mathrm{tä} \\
-\mathbf{a},-\ddot{a}\end{array}$ & $\begin{array}{l}-\mathrm{ta}, \mathrm{tä} \\
-\mathrm{a}, \ddot{a}\end{array}$ \\
\hline Sisseütlev & (illatiiv) & $\begin{array}{l}\text {-h-n } \\
\text { täishäälik + n } \\
\text {-seen (-sen) }\end{array}$ & $\begin{array}{l}\text {-hin } \\
\text {-in } \\
\text {-siin }\end{array}$ \\
\hline \multicolumn{4}{|c|}{ c. Käänded, mis eestis puuduvad } \\
\hline Instruktiiv & "keinonto" & $-\mathbf{n}$ & $-\mathbf{n}$ \\
\hline Komitatiiv & "seuranto" & & - ne \\
\hline
\end{tabular}


seikkaperäisesti myös päätevarianttien distribuutio (mts. 19-23). Sijamuotoja valaistaan esimerkein, mutta niiden erilaisiin käyttötapoihin ei kajota vielä muoto-opin vaan vasta lauseopin yhteydessä (mts. 92-112). Lauseopillisessa kuvauksessa sijoista käytetään ensisijaisesti latinalaisperäisiä nimityksiä, ja nyt puolestaan vironkieliset nimitykset ovat sulkeissa. Sijoja käsitellään myös eri järjestyksessä kuin muoto-opin yhteydessä. Ensiksi käydään läpi nominatiivin ja genetiivin syntaktiset tehtävät, niiden jälkeen tulevat yleiset paikallissijat essiivi, partitiivi ja translatiivi, sitten sisä- ja ulkopaikallissijat ja lopuksi komitatiivi, instruktiivi ja abessiivi; akkusatiivia Kettunen käsittelee jonkin verran objektin yhteydessä (mts. 86-88). Sijojen syntaktista käyttöä koskeva osio on paljolti pelkkä esimerkkikokoelma, jossa taustoittavaa tekstiä on varsin vähän, ja painopiste on nytkin suomen ja viron eroissa. Kaiken kaikkiaan Kettusen oppikirja vaikuttaa pikemminkin kontrastiivisesta näkökulmasta kirjoitetulta oppijan kieliopilta kuin varsinaiselta oppikirjalta (vrt. Götze 2001: 188-198).

\section{Lopuksi}

Olen tarkastellut M. Wellewillin vuonna 1919 ilmestynyttä Soome keele óperaamatua ja etsinyt vastausta kysymykseen, millainen oppikirja se oikein on. Tätä kysymystä lähestyin kahdesta näkökulmasta. Ensiksi tarkastelin Õperaamatua saksan kielestä ja saksankieliselle kohderyhmälle kirjoitetun oppikirjan käännöksenä. Arvelin, että käännöksessä hyödynnettäisiin jollain tapaa suomen ja viron samankaltaisuutta, mikä tietysti tarkoittaisi poikkeamista saksankielisestä lähtötekstistä. Poikkeamat osoittautuivat kuitenkin melko vähäisiksi. Õperaamatusta on toki poistettu kaikki saksan ja suomen kielen vertailua koskevat kohdat, joita lähtötekstissä on kuitenkin varsin vähän. Jonkin verran kieliopin selityksiin on lisätty viron ja suomen samankaltaisuutta korostavia huomautuksia, mutta niitäkin on vain harvakseltaan, eniten äänneopin yhteydessä. Õperaamatun kääntäjä on siis toiminut sangen varovaisesti ja säilyttänyt lähtötekstin perusratkaisut sellaisinaan. Toisaalta arvelin, 
että Õperaamatussa näkyisi jollain tapaa virolaisen ja suomalaisen kulttuurin läheisyys. Tässä suhteessa Õperaamat kuitenkin pitäytyy joitakin melko merkityksettömiä muutoksia lukuun ottamatta lähtötekstissä, eikä tekstistä ole poistettu kuin vain muutama alaviite, esimerkiksi viite suomalaiseen saunomiskulttuuriin. Vähäinen tarve muutoksiin johtuu siitä, että lähtötekstissäkään kulttuuriset erot eivät nouse esiin.

Toinen näkökulmani koski Õperaamatun suhdetta Aavikin (1908) ja Kettusen (1920) oppikirjoihin. Kooten voi todeta, että kaikki kolme oppikirjaa eroavat toisistaan kohderyhmänsä, tavoitteidensa, painotustensa ja esitystapansa puolesta. Aavikin ja Kettusen oppikirjoille on yhteistä se, että ne on laadittu lähinnä akateemisille oppijoille, jotka omaavat jo jonkinlaisia taustatietoja suomen kielestä ja joilla on hyvät kieliopilliset valmiudet täydentää tietojaan. Oppikirjoilla on kuitenkin varsin erilaiset tavoitteet ja painotukset, mikä heijastuu niiden tapaan kuvata suomen kieltä. Aavik tähtää kielitaitoon, joka mahdollistaisi suomenkielisen kirjallisuuden lukemisen, Kettunen taas lähinnä kielitietoon ja kieliopin kokonaiskuvan hahmottamiseen, vaikka mainitsee esipuheessaan tavoitteeksi myös käytännön kielitaidon. Aavik etenee kieliopin kuvauksessa tavoitteidensa kannalta parhaaksi katsomassaan järjestyksessä ja niputtaa vasta oppikirjansa loppupuolella keskeiset kielioppiseikat kokonaisuuksiksi. Kettunen puolestaan on rakentanut koko oppikirjansa kieliopin kuvaustasojen mukaan edeten äänneopista muoto-opin kautta lauseoppiin, niin että oppikirja muistuttaa oppijan kielioppia. Koska Õperaamat on melko perinnäisellä tavalla kielioppikäännös-menetelmään nojaava oppikirja, sillä on hyvin vähän mitään yhteistä Kettusen oppikirjan kanssa. Aavikin oppikirjaankin sitä yhdistää oikeastaan vain se, että kieliopillinen aines esitetään pieninä kokonaisuuksina oppijan ja opetustavoitteiden kannalta hyväksi katsotussa järjestyksessä. Õperaamatun selvimpiä eroja Aavikin ja Kettusen oppikirjoihin ovat kohderyhmän lisäksi käytännön kielitaitoon tähtäävä esitystapa, jossa kieliopin ohella myös sanaston oppimisella on keskeinen tehtävä ja jossa kieliopin ja sanaston käyttöä harjoitellaan käännös- ja keskusteluharjoitusten avulla. Kaikilla kolmella kieliopilla on 
vahvuutensa ja heikkoutensa, niin että ne myös täydentävät toisiaan. Erilaisuutensa vuoksi kaikille kolmelle on varmasti löytynyt myös käyttöä ja omat kannattajansa 1900-luvun alun vironkielisten suomenoppijoiden parissa.

\section{Aineisto}

Aavik, Johannes 1908. Praktilik Soome keele õpetus. Helsingis: Yrjö Weilin'i kirjastus.

Kettunen, Lauri 1920. Soome keele õpiraamat. Tallinnas: K./U. Rahvaülikool.

Wellewill, M. 1890 [ $\left.{ }^{2} 1906,{ }^{3} 1922\right]$. Praktische Grammatik der Finnischen Sprache für den Selbstunterricht. Mit Lesestücken, Gesprächen und Wörterbuch. Wien/Pest/Leipzig: A. Hartleben's Verlag.

Wellewill, M. 1919. Soome keele õperaamat iseõppijatele. Grammatik, kõnelemised, harjutused ja sõnastik. Tallinn: J. \& A. Paalmann.

\section{Kieliopit ja oppikirjat}

Eurén, Gustaf Erik 1849. Finsk språklära. Åbo: J. C. Frenckell \& Son.

Hermann, Karl August 1884. Eesti keele Grammatik: Koolide ja iseõppimise tarvis kõikidele, kes Eesti keelt õigesti ja puhtasti kõnelema ja kirjutama ning sügavamalt tundma ja uurima tahawad õppida. Tartus: Trükitud Wilhelm Jus'i juues.

Kockström, V[iktor] R[einhold] 1876. Kurze Grammatik der Finnischen Sprache. Nach dem Schwedischen bearbeitet von K. Suomalainen. Helsingfors: G.W. Edlund.

Kockström, V[iktor] R[einhold] 2 1881 . Lärobok i finska språket. Omarbetad upplaga. Helsingfors: G.W. Edlund. [Ensimmäinen painos 1868.]

Neumann, M. 1903. Lühikene Soome keele grammatika ja niisuguste sõnade Sõnastik, mis Eesti keelest lahku lähewad. Tallin: M. Neumanni kirjastus.

Weske, Michael 1873. Untersuchungen zur vergleichenden Grammatik des finnischen Sprachstammes. Leipzig: Druck und Verlag von Breitkopf und Härtel.

Weske, M. 1881. Soome keele õpetus. Esimene jagu: Lühikene grammatik. Wiljandis: Trükitud F. Feldt’i kulu ja kirjadega. 
SAKSAN KIELESTÄ VIRONNETTU SUOMEN KIELEN OPPIKIRJA ...

\section{Lähteet}

Elomaa, Eeva 2009. Eläköön oppikirja! Teoreettisia ja käytännön näkökohtia kielten oppimateriaalien uudistamiseen ['Cheers to the Textbook! Theoretical and Practical Considerations on Enchancing Foreign Language Textbook Design']. Jyväskylä Studies in Humanities 122. Jyväskylä: Jyväskylän yliopisto.

Ernits, Villem 1929. Soome keele õpetamise küsimusi Eesti koolides ['Issues on teaching Finnish at Estonian schools']. - Eesti Hõim II (4), Detsember, 102-106.

Fäcke, Christiane 2016. Lehrwerkforschung - Lehrwerkgestaltung - Lehrwerkrezeption. Überlegungen zur Relevanz von Lehrwerken für den Fremdsprachenunterricht. - Michaela Rückl (Hrsg.). Sprachen und Kulturen: vermitteln und vernetzen. Beiträge zu Mehrsprachigkeit und Inter-/Transkulturalität im Unterricht, in Lehrwerken und in der Lehrer/inne/bildung. Münster \& New York: Waxmann, 34-48.

Gustafsson, Fridolf 1892. Literatur och läroböcker i språkundervisning, II. - Finsk tidskrift XXXII, 69-76.

Götze, Lutz 1994. Fünf Lehrwerkgenerationen. - Bernd Kast, Gerhard Neuner (Hrsg.). Zur Analyse, Begutachung und Entwicklung von Lehrwerken. Berlin \& München: Langenscheidt, 29-30.

Götze, Lutz 2001. Linguistische und didaktische Grammatik. - Gerhard Helbig, Lutz Götze, Gert Henrici, Hans-Jürgen Krumm (Hrsg.). Deutsch als Fremdsprache. Handbücher zur Sprach- und Kommunkationswissenschaft 19.1. Berlin \& New Work: Walter de Gruyter, 187-194.

Järventausta, Marja 2017. Kaksi saksankielistä suomen kielen oppikirjaa sadan vuoden takaa ['Two textbooks for Finnish written in the German language hundred years ago']. - Ulla Tuomarla, Iwona Piechnik, Bernadett Bíró (Eds.). Finland. Suomi 100 - Language, Culture, History. Kraków \& Helsinki: Jagiellonian Library \& University of Helsinki, 64-77.

Kasik, Reet 1999. Johdatus viron kielen tutkimukseen ['Introduction to Estonian Language Studies']. Castrenianumin toimitteita 55. Helsinki: Suomalaisugrilainen laitos; Suomalais-Ugrilainen Seura.

Kok, Maria 2018. Suomen sijamuotojen nimitykset: kuinka käsiteanalyysi ja tuotekehittely 1800-luvun kieliopeissa saataisiin hyödyttämään S2- ja äidinkielen opetusta? ['On the naming system of the Finnish nominal cases: Concept analysis and product development in the 19th century Finnish 
grammars']. - Lähivertailuja 28, 143-177. https://dx.doi.org/10.5128/ LV28.04

Krumm, Hans-Jürgen 2010. Lehrwerke im Deutsch als Fremd- und Deutsch als Zweitsprache-Unterricht. - Hans-Jürgen Krumm, Christian Fandrych, Britta Hufeisen, Claudia Riemer (Hrsg.). Deutsch als Fremd- und Zweweitsprache. Handbücher zur Sprach- und Kommunikationswissenschaft 35.2. Berlin \& New York: De Gruyter Mouton, 1215-1227.

MLZ = Metzler Lexikon Fremdsprachendidaktik 22017. Carola Surkamp (Hrsg.). 2., aktualisierte und erweiterte Auflage. Stuttgart: J. B. Metzler.

Reinfried, Marcus 2016. Geschichte des Fremdsprachenunterrichts bis 1945. - Eva Burwitz-Melzer, Gert Mehlhorn, Claudia Riemer, Karl-Richard Bausch, Hans-Jürgen Krumm (Hrsg.). Handbuch Fremdsprachenunterricht. 6., völlig überarbeitete und erweiterte Auflage. Tübingen: A. Francke Verlag, 619-625.

Rösler, Dietmar, Michael Schart 2016. Die Perspektivenvielfalt der Lehrwerkanalyse - und ihr weißer Fleck. Einführung in zwei Themenhefte. - Info DaF 5, 483-493.

Setälä, E[emil] N[estor] 1891. Suomen kielioppeja ulkomaalaisille ['Finnish textbooks for foreign language learners']. [Kirjallinen katsaus.] - Valvoja 11 (3), 190-192.

Valge, Jüri 1987. Suomea virolaisille: teoksia, tekijöitä, taustaa ['Finnish for Estonians']. - Sananjalka 29, 175-185.

Vehkanen, Marjut 2017. Kaksi tapaa opettaa suomea vieraana kielenä - Johannes Aavikin (1902) Praktilik Soome keele õpetus ja Béla Györffyn (1939) Gyakorlati finn nyelvkönyv ['Two ways of teaching Finnish as a foreign language']. - Lähivertailuja 27, 242-277. https://doi.org/10.5128/LV27.08

Vehkanen, Marjut 2018. Suomi vieraana kielenä -oppikirjojen sisältöjen suhde oman aikansa ilmiöihin: Johannes Aavikin Praktilik Soome keele õpetus (1902) ja Béla Györffyn Gyakorlati Finn Nyelvkönyv (1939) ['The relationship of the text contents of the Finnish as a foreign language textbooks with the phenomena of their own time']. - Lähivertailuja 28, 392-422. https:// doi.org/10.5128/LV28.12 


\title{
An Estonian textbook for Finnish, translated from German - Soome keele õperaamat iseõppijatele (1919)
}

\author{
MARJA JÄRVENTAUSTA \\ University of Gologne
}

M. Wellewills's textbook for Finnish appeared in Estonia under the name Soome keele opperaamat iseoppijatele in 1919. The name of the author is a pseudonym, and the textbook itself is a translation of the German textbook Praktische Grammatik der Finnischen Sprache für den Selbstunterricht, published in 1890. This article deals with whether and to what extent the Estonian translation differs from the German original. It can be assumed that the linguistic affinity between Estonian and Finnish, as well as the cultural proximity between Estonia and Finland, will cause some changes. On the other hand, the question of how Ôperaamat differs from Johannes Aavik's Praktilik Soome keele õpetus (1908) and Lauri Kettunen's Soome keele ópiraamat (1920) is examined. It can be shown that Opperaamat differs only slightly from its German original. The difference to the two contemporary textbooks is more striking because Opperaamat is still structured strictly according to the traditional grammar-translation method.

Keywords: historical textbook research; Finnish as a foreign language; Finnish textbooks in Estonia 